\title{
EVERYTHING IS PERMIT'TED: SEBUAH ULASAN SINGKAT \\ IL PRINCIPE KARYA MACHIAVELLI
}

\author{
Galuh Febri Putra
}

PBI UAD

E-mail: feb_putra08@yahoo.com

Judul : IL PrINCIPE | Pengarang : NicColo Machiaveldi |

Penerbit: NARAsi | Tahun terbit: 2014 | Jumlah HALAMAN: 184 |

$\mathrm{T}$ idak diketahui di mana buku ini 'transit' sehingga perlu berabad-abad untuk mendarat di Indonesia. Buku ini terbilang sangat tua karena pertama kali diterbitkan pada abad ke-16 awal dan kemungkinan telah dicetak sebanyak milyaran kopi. Pada masanya buku ini merupakan salah satu buku terpopuler yang hanya kalah dengan komedi ilahiyah Dante's Inferno. Buku ini dapat bertahan dalam bengisnya waktu karena isinya yang luar biasa dan penuh kontroversi. Mungkin karena isinya yang kontroversial tersebut, buku ini memerlukan waktu yang panjang untuk dapat mendarat di Indonesia. Buku ini secara garis besar membahas tentang apa yang harus dilakukan oleh pemimpin untuk mempertahankan kekuasaannya atau bahkan melebarkan kekuasaannya. Buku ini terdiri dari dua puluh enam bab dimana masing-masing bab membahas tentang cara menjadi seorang pemimpin yang dapat mempertahankan kekuasaannya.

Pandangan-pandangan yang diuraikan oleh Machiavelli dalam Il Principe mungkin kedengarannya ekstrim. Namun jika melihat bahwa seluruh kehidupannya dihabiskan di Firenze pada saat konflik politik yang berkelanjutan, buku tersebut dinilai sangat realistik dan kemungkinan dapat digunakan sebagai teks sejarah yang mempunyai nilai autentisitas tinggi. Fokus penulisan Machiavelli bukanlah tentang sebuah politik yang bersih dan beretika luhur. Nilai utama yang ditekankan Machiavelli adalah kebutuhan akan stabilitas dalam wilayah seorang pangeran/penguasa. Il Principe secara luas dianggap sebagai salah satu buku yang paling berpengaruh dalam politik, khususnya menyangkut pemerolehan, pelestarian, dan penggunaan kekuasaan politik di dunia Barat. Pengamatan-pengamatan Machiavelli terus bergema melalui para politikus, mahasiswa, dan sarjana. Ketika Machiavelli menulis Il Principe, ia tidak bermaksud untuk menyusun sebuah tulisan ilmiah tentang teori politik, tapi tulisan tersebut disukai oleh keluarga Medici yang berkuasa, yang dirasakan memberikan nasihat tentang bagaimana seorang penguasa dapat memperoleh dan mempertahankan kekuasaan.

Teori-teori yang diungkapkan dalam Il Principe seringkali dianggap sebagai metode cerdas namun tidak bermoral yang dapat digunakan oleh penguasa yang sedang mencari kekuasaan untuk memperoleh takhta, atau oleh seorang penguasa untuk mengukuhkan pemerintahannya. Karena dianggap tidak bermoral maka buku ini baru bisa dipublikasikan lima tahun setelah meninggalnya Machiavelli atas seizin Paus Clementus VII. Moral yang dibangun oleh Machiavelli kemungkinan 
besar sangat berbeda dengan moral yang diwacanakan gereja Katolik waktu itu dan juga definisi moral yang berkembang di Indonesia mengingat lamanya waktu untuk buku itu terbit di Indonesia

Menurut Machiavelli, kebaikan moral yang terbesar adalah sebuah negara, yang bajik (virtuous) dan stabil. Jadi untuk membuat negara yang bajik diperlukan tindakan-tindakan untuk melindungi negara, betapapun kejamnya dapat dibenarkan. Walaupun Machiavelli dalam bukunya berbicara bahwa kekuasaan harus dipertahankan walaupun dengan cara terkejam sekalipun, namun Machiavelli sangat menganjurkan bahwa terutama sekali Sang Penguasa tidak boleh dibenci. Ia memberikan sebuah jawaban yang padat tentang apakah seorang penguasa harus ditakuti dan atau dicintai. Ia menyatakan, “...seorang penguasa yang bijaksana harus membangun kekuasaannya berdasarkan apa yang ia kuasai sendiri dan bukan berdasarkan apa yang dikuasai orang lain; ia harus berusaha agar ia tidak dibenci, seperti yang telah dicatat." Ia juga berkata "Yang terbaik ialah ditakuti dan dicintai; namun demikian, bila seseorang tidak dapat dua-duanya, lebih baik ditakuti daripada dicintai."

Pada bab-bab awal buku ini, Machiavelli mendefinisikan metode-metode pemerintahan yang efektif dalam beberapa bentuk kepenguasaan. Machiavelli menjelaskan kepada pembacanya dengan merujuk pada salah seorang anggota keluarga bangsawan Firenze. Metode-metode yang digambarkan di dalamnya mencakup pengajaran tentang perang dan kekejaman. Il Principe dimulai dengan menggambarkan subjek yang akan ditangani ketika akan merenggut atau mempertahankan kekuasaan. Dalam kalimat pertama Machiavelli menggunakan kata "negara" (stato Italia yang juga bisa berarti "Status") untuk menutupi semua bentuk organisasi kekuasaan politik tertinggi, baik republik maupun kerajaan. Pada bab awal buku ini Machiavelli juga mengungkapkan bagaimana kata "negara" muncul sebagai bentuk dari pemaknaan modern terhadap ruang pada masa Renaisans. Oleh karenanya Machiavelli menganjurkan penggunaan kata tersebut guna menutupi kekejaman yang perlu dilakukan, dan penguasa tetap dicintai oleh rakyatnya

Machiavelli membedakan negara baru dan negara keturunan dimana untuk menjadi penguasa dari kedua bentuk negara tersebut dibutuhkan cara yang berbeda. Pada bab kedua Machiavelli mengatakan bahwa bentuk negara keturunan lebih mudah untuk mengatur pemerintahan karena negara keturunan mempunyai homogenitas sehingga dapat menerapkan undang-undang dan perpajakan tanpa adanya perlawanan atau ketidaksetujuan dari masyarakat. Catatan Machiavelli untuk penguasa negara keturunan adalah bahwa sang penguasa tidak akan dibenci oleh rakyatnya kecuali dia melakukan kejahatan yang teramat besar, sehingga kemungkinan sedikit usaha untuk menunjukkan kekuasaan militer tidak akan membuatrakyatberpalingmuka dari hadapannya (Gilbert, 1938: 19-23). Dibandingkan dengan presentasi saran tradisional untuk penguasa, buku ini mengungkapkan hal-hal baru dalam bab 1 dan 2. Hal yang ditemukan oleh Gilbert adalah "tujuan sengaja penguasa baru adalah perlu membangun dirinya menyimpang dari kebiasaan". Ia berpendapat bahwa Machiavelli mungkin telah dipengaruhi oleh Tacitus serta pengalamannya sendiri. Kategorisasi rezim yang dilakukan oleh Machiavelli tampaknya lebih sederhana dari yang tradisional misalnya dalam Politik ala Aristoteles yang membagi rezim pemerintahan menjadi: seorang raja tunggal, oligarki, negara yang dipimpin oleh orang banyak dan demokrasi. Ia juga mengabaikan perbedaan klasik antara bentuk yang baik dan korup, misalnya antara monarki dan tirani. Strauss (1958: 272) menunjukkan bahwa Machiavelli sering menggunakan katakata "pangeran" dan "tiran" sebagai sinonim, "terlepas dari apakah ia berbicara tentang pidana atau non-kriminal tiran". 
Pada bab ke-6 sampai ke-8, secara khusus Machiavelli membahas tentang negara yang benar-benar baru. Penguasa yang naik ke kekuasaan melalui keterampilan mereka sendiri dan sumber daya ("kebajikan" mereka) daripada keberuntungan cenderung memiliki waktu yang lebih lama dan kesukaran naik ke atas, tetapi setelah mereka mencapai puncak mereka sangat aman di posisi mereka. Hal ini karena mereka secara efektif menghancurkan lawanlawan mereka dan mendapatkan rasa hormat yang besar dari orang lain. Oleh karena mereka kuat dan lebih mandiri, mereka harus membuat sedikit kompromi dengan sekutu mereka.

Machiavelli menulis bahwa reformasi pemerintah yang ada adalah salah satu hal yang paling berbahaya dan sulit untuk dilakukan. Alasannya adalah bahwa orang secara alami resisten terhadap perubahan dan reformasi. Mereka yang diuntungkan dari tatanan lama akan menolak perubahan dengan sangat keras. Sebaliknya, mereka yang memperoleh manfaat dari peraturan baru akan kurang militan untuk mendukung sang penguasa. Selain itu, tidak mungkin bagi sang penguasa untuk memenuhi harapan semua orang. Tak pelak, ia akan mengecewakan beberapa pengikutnya. Oleh karena itu, pangeran harus memiliki sarana untuk memaksa para pendukungnya untuk bertahan. Machiavelli mengangap bahwa hanya nabi bersenjata, seperti Musa yang berhasil membawa perubahan abadi. Machiavelli mengklaim bahwa Musa telah membunuh banyak orang untuk menegakkan kehendak Tuhan. Menurut Gilbert (1938: 39) bahwa tunjuan Machiavelli menulis hal tersebut yaitu untuk melanggengkan perilaku korup yang sangat sistematis di Italia pada waktu itu.

Machiavelli menyarankan bahwa penguasa harus berhati-hati menghitung semua perbuatan amoral yang perlu dia lakukan untuk mengamankan kekuasaannya, dan kemudian mengeksekusi mereka semua dalam satu 'serangan', sehingga ia tidak perlu melakukan kejahatan lebih untuk sisa pemerintahannya.
Dengan cara ini, rakyatnya perlahan akan melupakan perbuatan kejam dan reputasinya bisa sembuh. Penguasa yang gagal melakukan hal ini dan yang ragu-ragu dalam berbuat kezaliman, akan menemukan masalah yang menjamur dari waktu ke waktu dan mereka dipaksa untuk melakukan perbuatan jahat sepanjang pemerintahan mereka. Jadi mereka terus-menerus merusak reputasi mereka dan merusak reputasi mereka sendiri.

Jenis perilaku politik yang dibahas jelas oleh Machiavelli dalam Il Principe dianggap sebagai tulisan yang mengejutkan pada zamannya ketika amoralitas masih menjadi subjek diskusi serius. Meskipun menyarankan penguasa bagaimana berbuat tirani, Machiavelli umumnya dianggap sangat realis menyibak realitas kebusukan politik pada waktu itu. Strauss (1958: 11) mengutarakan "bahkan jika kita dipaksa untuk mengakui bahwa Machiavelli pada dasarnya adalah seorang patriot atau ilmuwan, kita tidak akan dipaksa untuk menyangkal bahwa ia adalah seorang guru yang jahat".

Machiavelli menekankan perlunya realisme sebagai lawan idealisme. Dalam Il Pripcipe ia tidak menjelaskan apa yang disebut sebagai tujuan etis atau politik. Fischer (2000: 75) mengatakan, bahkan meski agak kontroversial, Machiavelli jauh melampaui penulis lain pada masanya, yang menurut pendapatnya meninggalkan hal-hal yang sebenarmya terjadi, dan oleh karena itu penguasa menjadi buruk karena keyakinan Kristen mereka. Machiavelli menggunakan kata-kata "kebajikan" dan "kehati-hatian" untuk merujuk kepada kemuliaan dan keunggulan semangat, yang menurutnya berbeda tajam dengan apa yang telah dibangun oleh wacana Kristen tradisional. Ia mendorong ambisi dan pengambilan risiko. Oleh karenanya, berbeda dengan tradisi Kristen, ia menyarakan tidak hanya stabilitas, tetapi juga radikalisasi tindakan untuk mencapai tujuan dalam komunitas politik.

Machiavelli sangat dipengaruhi oleh 
filsafat politik pra-Kristen klasik. Menurut Strauss (1958: 291), Machiavelli mengacu Xenophon lebih dari Plato, Aristoteles, dan Cicero. Gilbert (1938: 236) menulis: "Xenophon adalah pahlawan bagi banyak pria sastra abad keenam belas, tapi untuk Machiavelli ia hidup". Strauss (1958: 291) menunjukkan dialog bahwa Hiero sebagai orang bijak sangat simpati pada seorang tiran. Menurut Strauss hal itu mendekati apa yang ditulis Machiavelli dalam membentuk deskripsi 'Penguasa Ideal'. Plato dan Aristoteles, adalah pengikut Socrates, dan karya-karyanya menunjukkan persetujuan dari "argumen teleologis", sedangkan Machiavelli menolak argumen tersebut. Walaupun Strauss (1958: 222-223) memberikan bukti bahwa Machiavelli mungkin telah belajar sesuatu dari Democritus, Epicurus dan materialisme klasik, dan melihat tulisannya tidak terkait dengan realisme politik atau bahkan kepentingan politik yang terjadi pada saat itu, pada akhirnya Machiavelli menawarkan model sistem etika yang tidak hanya membenarkan praktik kekerasan dan penipuan, tetapi tampaknya hal tersebut juga telah menjadi kebiasaan dan erat dalam kegiatan politik.

\section{Daftar Pustaka}

Fischer, Markus. 2000. Well-ordered License: On the Unity of Machiavelli's Thought. Lexington Book.

Gilbert, Allan. 1938, Machiavelli's Prince and Its Forerunners. Duke University Press.

Strauss, Leo. 1958. Thoughts on Machiavelli. University of Chicago Press. 